\title{
Spatial Distribution of Aphanomyces cochlioides and Root Rot in Sugar Beet Fields
}

\author{
Julie W. Beale, Diagnostician/Research Specialist, University of Kentucky, Lexington 40546; Carol E. Windels, \\ Professor, University of Minnesota, Northwest Research and Outreach Center, Crookston 56716; and Linda L. \\ Kinkel, Professor, University of Minnesota, St. Paul 55108
}

\begin{abstract}
Beale, J. W., Windels, C. E., and Kinkel, L. L. 2002. Spatial distribution of Aphanomyces cochlioides and root rot in sugar beet fields. Plant Dis. 86:547-551.

Spatial distribution of Aphanomyces cochlioides inoculum and disease was assessed in sugar beet fields located near Moorhead, MN and Wahpeton, ND. Soil samples were collected in June and July 1994 from two main plots (60 by $60 \mathrm{~m}$ ) in each field. Samples were evaluated for $A$. cochlioides using a sugar beet seedling assay in the greenhouse to determine a root rot index value (0-to-100 scale), which served as an indirect estimate of relative activity and density of inoculum. Field evaluations of Aphanomyces root rot on sugar beet (0-to- 7 scale) were made at harvest in September at each soil collection site. Greenhouse root rot index values correlated positively with field disease ratings for all plots. Variance-to-mean ratios of greenhouse root rot index values and of field disease ratings among samples within each plot were calculated to compare the spatial distribution of midseason inoculum with root rot at harvest. Ratios of greenhouse root rot indices indicated that inoculum of A. cochlioides was aggregated in the field at midseason, but root rot was uniform within plots by harvest. Wet weather in July through August was conducive to infection and development of symptoms. A uniform distribution of disease at harvest likely reflects a combination of factors, including root growth into inoculum foci, redistribution of inoculum, and inoculum densities that are spatially variable but all above some minimum threshold for infection.
\end{abstract}

Additional keywords: Beta vulgaris

Aphanomyces cochlioides Drechs. is a serious pathogen of sugar beet (Beta vulgaris L.) in the United States, Canada, Chile, Japan, and Europe $(3,7,10,12,14)$. When soil conditions are moist and warm (22 to $28^{\circ} \mathrm{C}$ ), disease can occur in two phases: an acute seedling blight and a chronic root rot (also called black root) of older plants $(10,12)$. Aphanomyces root rot of sugar beet has increased in economic importance in the Red River Valley of Minnesota and North Dakota throughout the 1990s because of wet weather and shorter rotations between sugar beet crops (prompted by a decrease in wheat and barley production). Chronic root rot has been more prominent than acute seedling blight and has varied from mild to severe, depending upon the region, field, local weather conditions, and adoption of control practices. In 1999, about $51 \%$ of over 293,000 ha of land sown to sugar beet in

Corresponding author: C. E. Windels

E-mail: cwindels@tc.umn.edu

Partial funding in support of this research was provided by the Sugarbeet Research and Education Board of Minnesota and North Dakota.

Accepted for publication 16 January 2002.

Publication no. D-2002-0318-02R

(C) 2002 The American Phytopathological Society
Minnesota and North Dakota was infested with A. cochlioides (B. J. Jacobsen, personal communication).

Oospores of A. cochlioides persist in soil for years in the absence of a sugar beet crop (14,20); therefore, disease management is advised when infested fields are sown to beets. Because there is no direct method to quantify populations of $A$. cochlioides in soil, the root rot index value derived from a greenhouse seedling assay serves as an indirect estimate of relative activity and density of inoculum in soil. Indexing sugar beet fields for $A$. cochlioides $(9,21)$ currently is used by the sugar beet industry in Minnesota and North Dakota to assist producers with these decisions (C. E. Windels, unpublished data). Control measures include seed treatment with hymexazol (Tachigaren, Sankyo Co., Ltd., Tokyo, Japan), early planting to avoid soil conditions that favor disease, management of soil moisture (installing drainage tiles or ditches, cultivating), weed control, soil fertilization, and plant resistance (20). When index values are high, producers are cautioned to avoid planting sugar beet because the effectiveness of control measures is limited when weather becomes favorable for infections $(17,20)$.

Aphanomyces disease symptoms vary in intensity from mild to severe, and affected areas can range from a meter in diameter to as large as an entire field (20). This spatial variation may result from variable densities of inoculum or abiotic factors that influence disease development throughout the growing season (15). No data are available, however, to document the relationship between early- or midseason distribution of inoculum of $A$. cochlioides and the distribution and severity of disease at harvest within fields. Our research examines the midseason spatial distribution and relative inoculum densities of $A$. cochlioides, based on greenhouse root rot index values, in relation to the distribution and severity of root rot in the field at harvest. A brief report has been published (1).

\section{MATERIALS AND METHODS}

Field plots. In 1994, plots were established in two commercial sugar beet fields with a history of patchy distribution of Aphanomyces root rot (grower-cooperators previously had observed diseased and disease-free areas in the fields). Both fields had not been sown to sugar beet since 1991. The field near Moorhead, MN consisted of 38.0 ha of Bearden (Aeric calciquoll; fine, silty, frigid) -Colvin (Typic calciquoll; fine, silty, frigid) soil association with a $1 \%$ slope. Sugar beet cv. American Crystal Hybrid 192 was sown on 13 May 1994 at an 11- to $12-\mathrm{cm}$ spacing with rows spaced $0.6 \mathrm{~m}$ apart. The field near Wahpeton, ND consisted of 50.6 ha of a Fargo (Vertic haploquoll; fine, montmorrillonitic, frigid) -Ryan (Typic natraquoll; fine, montmorrillonitic, frigid) soil with a 0 to $1 \%$ slope. Sugar beet cv. Van der Have H66156 was sown on 12 May 1994 at an 11- to 12-cm spacing with rows spaced 0.8 $\mathrm{m}$ apart. Both cultivars are susceptible to A. cochlioides. Fields were maintained by each producer according to recommended production practices (4).

Main plots were established at opposite ends of each field at least $100 \mathrm{~m}$ from the edges to avoid possible border effects of headlands. Plot areas, selected in consultation with the grower-cooperators, were about $600 \mathrm{~m}$ apart at the Moorhead site and about $750 \mathrm{~m}$ apart at the Wahpeton site. One main plot in each field was located in an apparently disease-free area (plot 1 at Moorhead and plot 3 at Wahpeton) and the other in an area with a history of disease (plot 2 at Moorhead and plot 4 at Wahpeton). Main plots were 60 by $60 \mathrm{~m}$ and were divided into nine equal subplots of 20 by $20 \mathrm{~m}$. Within each subplot, 11 sample 
points were selected by computer-generated random numbers. A 3-m length of row was measured from each point for the purposes of counting stands and collecting soil samples at midseason and for assessing 99 3-m-length areas were sampled per main plot.

Soil collection and greenhouse assay. Each soil sample (99 per main plot) consisted of eight soil cores $(5.5 \mathrm{~cm}$ in diameter by $15 \mathrm{~cm}$ in depth) collected at equal distances between plants (approximately $18 \mathrm{~cm}$ apart) within a 3-m length of row. Soil cores from a single 3-m row length were combined in a paper bag and stored at $22 \pm 2^{\circ} \mathrm{C}$ for no more than 5 days. Soil samples were collected at Moorhead on 16 June and 28 July 1994. Half of the samples from the disease-free plot were collected on the earlier date, but heavy rains followed by pesticide applications to control Cercospora leaf spot prevented re-entry into this field until 28 July. At that time, remaining samples from the reported disease-free plot and all samples from the plot with a history of disease were collected. Soil samples were collected at Wahpeton on 20 to 21 June 1994. Symptoms of Aphanomyces root rot (blackened and shriveled hypocotyls and tap roots, plant stunting, yellowed and upright leaves, uneven stands) were not observed in either field when soil samples were collected.

Root rot index values of soil samples were determined in the greenhouse to provide an indirect estimate of $A$. cochlioides inoculum densities. Each soil sample was passed through a $0.6-\mathrm{cm}$ mesh screen to break soil clumps and remove debris and then was mixed by shaking vigorously for $3 \mathrm{~min}$. Screens and mixing containers were Aphanomyces root rot at harvest. A total of

washed thoroughly and sprayed with $95 \%$ ethanol between samples to avoid crosscontamination. Each soil sample was equally distributed into five plastic pots ( 11.5 by 11.5 by $11.5 \mathrm{~cm}, 650 \mathrm{cc}$ soil/pot) and sown with 25 sugar beet cv. Maribo Ultramono (susceptible to A. cochlioides) seed/pot at a 2-cm depth. Seed sown in the soil from Moorhead was treated with metalaxyl (50 WP, $0.3 \mathrm{~g}$ a.i. $/ \mathrm{kg}$ seed) to control Pythium spp. Rhizoctonia solani also was present in the field at Wahpeton, so the metalaxyl seed treatment was supplemented with chloroneb (65 WP, $2.4 \mathrm{~g}$ a.i./kg seed). Pots were arranged in a completely randomized design and maintained in the greenhouse at $26 \pm 2^{\circ} \mathrm{C}$ for 4 weeks. Illumination was provided by natural light supplemented with high-pressure sodium lamps $\left(1,000 \mu \mathrm{E} \mathrm{m}^{-2} \mathrm{~s}^{-1}\right)$ for $16 \mathrm{~h}$ per day. Soil was kept moist by watering twice daily.

Stand counts were made at 6 to 7 days after planting and then twice weekly for 3 weeks. Dead and dying seedlings were removed when stands were counted, washed in tap water, and severed below the cotyledons. Roots were treated with $0.5 \%$ $\mathrm{NaOCl}$ for 15 to $20 \mathrm{sec}$ and rinsed twice in sterile distilled water (SDW). Each root was incubated in $5 \mathrm{ml}$ of SDW for at least $48 \mathrm{~h}$ at $22^{\circ} \mathrm{C}$ and then examined microscopically for sporangia of $A$. cochlioides.

A modification of the Fink and Buchholtz (9) assay that included an assessment of root rot was done at 4 weeks after planting (21). All seedlings were removed from soil, washed in tap water and assessed for disease based on a rating system where $0=$ hypocotyl and roots healthy, 1 = hypocotyl light brown, 2 = hypocotyl moderately discolored, and 3 = hypocotyl completely

Table 1. Mean disease ratings and variance-to-mean ratios (VTM) of soil samples indexed for Aphanomyces cochlioides in a greenhouse assay and of sugar beet plants rated for root rot in four field plots at harvest ${ }^{\mathrm{w}}$

\begin{tabular}{|c|c|c|c|c|c|}
\hline \multirow[b]{2}{*}{ Location, plot } & \multirow[b]{2}{*}{ History $^{x}$} & \multicolumn{2}{|c|}{ Greenhouse rating } & \multicolumn{2}{|c|}{ Field rating } \\
\hline & & Root rot index ${ }^{y}$ & VTM & Root rot rating ${ }^{\mathrm{z}}$ & VTM \\
\hline \multicolumn{6}{|l|}{$\begin{array}{l}\text { Moorhead, } \\
\text { MN }\end{array}$} \\
\hline Plot 1 & - & $18.6 \mathrm{a}$ & 20.1 & $1.1 \mathrm{a}$ & 1.1 \\
\hline Plot 2 & + & $71.9 \mathrm{~b}$ & 6.8 & $3.5 \mathrm{~b}$ & 0.4 \\
\hline \multicolumn{6}{|l|}{ Wahpeton, ND } \\
\hline Plot 3 & - & $64.2 \mathrm{a}$ & 22.2 & $4.1 \mathrm{a}$ & 0.6 \\
\hline Plot 4 & + & $67.0 \mathrm{a}$ & 20.1 & $4.8 \mathrm{~b}$ & 0.8 \\
\hline
\end{tabular}

${ }^{\text {w }}$ VTM ratios to differentiate between uniform, random, and aggregated spatial pattern calculated using root rot index values from the greenhouse assay and root rot ratings from field assessment.

${ }^{x}$ Plot history: Aphanomyces root rot absent $=-$, present $=+$, based on observations of growercooperator in previous seasons of sugar beet production.

${ }^{y}$ Each value based on mean of 99 soil samples/main plot $(60$ by $60 \mathrm{~m})$. Soil samples were collected in late June to early July 1994 (eight cores, $5.5 \mathrm{~cm}$ in diameter by $15 \mathrm{~cm}$ in depth, collected in a 3$\mathrm{m}$ length of row, which were combined), assayed by planting 25 sugar beet seed per five pots in the greenhouse, and indexed for root rot $(0$-to- 100 scale, where $0=$ healthy and $100=$ all plants dead $)$ at 4 weeks after planting. For each location, values in columns followed by the same letter are not significantly different according to least significant difference $(P=0.05)$.

${ }^{\mathrm{z}}$ Each value based on mean of 99 sample sites rated per main plot. Each sample site was $3 \mathrm{~m}$ long (the same sites as for soil collection) and all sugar beet plants were rated for root rot (0-to-7 scale, where $0=$ healthy and $7=$ root completely rotted) in early September 1994. For each location, values in columns followed by the same letter are not significantly different according to least significant difference $(P=0.05)$. rotted or seedling dead. A root rot index value was calculated for each pot of soil: root rot index $=(\Sigma[$ rating $\times$ number of plants at each rating] $\times 100) /$ total number of emerged plants $\times 3$ (the maximum disease category). Then, a mean root rot index value was calculated based on the five pots of soil derived from each sample.

Root rot assessment in field. All sugar beet plants in each 3-m sample site were rated for Aphanomyces root rot at harvest on 7 September at Moorhead and on 8 September at Wahpeton. Roots were dug, brushed free of soil, and rated on a 0-to-7 scale $(0=$ healthy, $7=$ root completely rotted; 21). Approximately 3,000 roots were rated in each field.

Data analysis. For each field, mean root rot index values from the greenhouse assay were calculated for main plots (99 samples/plot) and subplots (11 samples/ subplot) and compared using analysis of variance (ANOVA) (Proc GLM; SAS Institute Inc., Cary, NC). Similarly, mean root rot ratings for plants in each field also were determined and compared using ANOVA. Means were separated by least significant difference $(P \leq 0.05)$. Pearson's correlation coefficient was used to evaluate the correlation between results of the greenhouse root rot index and disease severity for the same sampling sites in the field (13). To assess spatial distribution of A. cochlioides and disease severity in the field, sample variance-to-mean ratios were calculated for root rot index values determined in the greenhouse and root rot ratings in the field for main plots and subplots. Variance-to-mean ratios provide simple indicators of aggregation: values approximating 1 describe a random spatial distribution of disease or pathogen activity; values much larger than 1 imply aggregated disease or pathogen activity; and values much smaller than 1 describe a uniform distribution of disease or pathogen activity. The departure of the spatial pattern from the Poisson, or random distribution, was formally tested using the index of dispersion: $\mathrm{P}^{2}=s^{2}(n-1) / x$. The index of dispersion is distributed as a $\chi^{2}$ with $n-1$ degrees of freedom (19). If the index of dispersion value is within the acceptance range, then the hypothesis of a random distribution cannot be rejected. Very large or very small index values are consistent with a nonrandom spatial pattern.

\section{RESULTS}

Root rot indices based on a greenhouse assay. A. cochlioides was detected in all four main plots (Table 1). At the Moorhead site, the plot reported by the grower-cooperator as disease-free had a significantly lower mean index value (18.6) than the plot with an observed history of Aphanomyces root rot (71.9). At the Wahpeton site, mean index values were equally high in plots reported by the grower-cooperator as previously being 
disease-free and diseased (64.2 and 67, respectively). Within main plots, root rot index values sometimes were significantly different among subplots (Fig. 1A). Root rot index values in subplots ranged from a low of 2 in the previously reported diseasefree plot at Moorhead to a high of 97 in the historically diseased plot at Wahpeton.

Root rot index values also varied among the 99 sampling points (a 3-m length row) within each main plot. An example is illustrated in Figure 2A for plot 3 (Wahpeton, previously described as disease-free). A gradient of low to high index values occurs from left to right across this plot. Data are not shown for the other three main plots, but in plot 4 (Wahpeton, historically diseased), a gradient of high (>80) to lower index values (most between 20 and 60) occurred from left to right, respectively, across the plot. At Moorhead, index values for the 99 sampling points in plot 1 (previously described as disease-free) tended to be low $(<20)$ except in the lower right subplot, where many values were between 40 and 50. In plot 2 (historically diseased), index values usually were $>70$ except in the lower right subplot, where many values were between 40 and 60 .

Application of root rot index values in the greenhouse assay to indirectly measure inoculum of $A$. cochlioides revealed that inoculum was aggregated in each main plot and among subplots. Variance-to-mean ratios were substantially $>1$ in all main plots (Table 1) and the $\chi^{2}$ test showed that the Poisson distribution was inappropriate for describing the data $\left(\chi^{2}>133.5\right.$ for all plots; $P<0.05$; data not shown). Within individual subplots, root rot indices also indicated aggregation of inoculum (data not shown). In 31 of 36 subplots, the Poisson distribution was rejected for describing the data $\left(\chi^{2}>18.3 ; P<0.05\right)$ and in 34 of 36 of these subplots, variance-to-mean ratios were $>1$ (data not shown).

All dying seedlings collected in the greenhouse assay had symptoms typical of Aphanomyces root rot. A. cochlioides was isolated from $25.4 \%$ of dead seedlings, but limited recovery is typical with this pathogen (21). $R$. solani and Pythium spp. were isolated from $<0.1 \%$ of dead seedlings.

Root rot in the field at harvest. Root rot occurred in both fields, including plots with no previously reported history of Aphanomyces root rot (Table 1). Approximately $10 \%$ of the stand was lost in all sampling areas between late June and September, but these losses were not included in the disease ratings because a 10 to $15 \%$ loss in stand typically occurs in sugar beet fields, even when root rot is absent (C. E. Windels, unpublished data). At the Moorhead site, some root rot occurred in the historically disease-free plot, but the dis- ease rating was significantly lower (1.1) than in the historically diseased plot (3.5). Disease ratings in both plots at Wahpeton, ND were high (4.1 and 4.8), but were significantly higher in the historically diseased plot. Within main plots, mean root rot ratings differed significantly among subplots (Fig. 1B). Values ranged from a low of 0.5 in the previously reported disease-free plot at Moorhead to a high of 6.0 in the historically diseased plot at Wahpeton.

Mean root ratings varied among the 99 sampling points within each main plot and are illustrated for plot 3 (Wahpeton, previously described as disease-free; Fig. 2B). A gradient of low to high disease severity occurs from left to right across this plot that generally correspond to the greenhouse root rot index values (Fig. 2A). Only 1 of the 99 sampling points had a greenhouse root rot index value of 0 (Fig. 2A), but field-grown roots rated from the same location averaged a rating of 2.5 (Fig. 2B). Data are not shown for the other three main plots, but in plot 4 (Wahpeton, historically diseased), a gradient of very high $(>4.5)$ to lower root rot ratings (most <2.5) occurred from left to right, respectively, across the plot. At Moorhead, root rot ratings for the 99 sampling points in plot 1 (previously described as disease-free) were $<1$ except in the lower right subplot, where
Moorhead, MN site

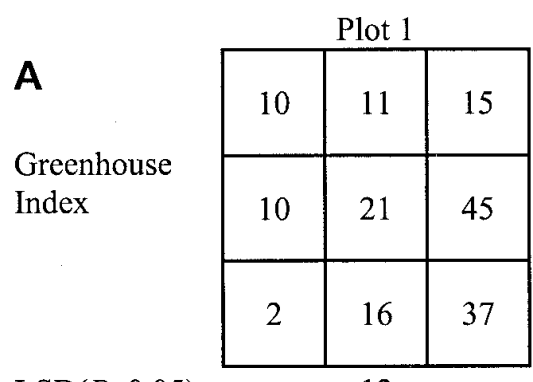

$\operatorname{LSD}(P=0.05)$ :

12

B

Field

Rating

\begin{tabular}{|c|c|c|c|}
\hline \multirow[t]{2}{*}{ Rating } & 0.5 & 1.2 & 2.2 \\
\hline & 0.5 & 1.0 & 2.6 \\
\hline
\end{tabular}

\begin{tabular}{|l|l|l|}
\multicolumn{1}{c}{ Plot 2 } \\
\hline 78 & 85 & 78 \\
\hline 74 & 71 & 60 \\
\hline 83 & 64 & 56 \\
\hline
\end{tabular}

17

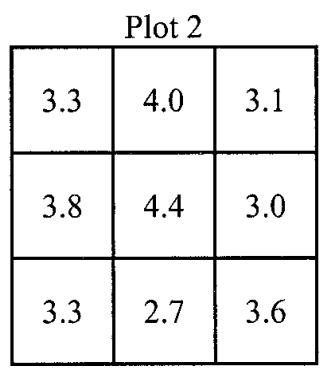

0.9

Wahpeton, ND site

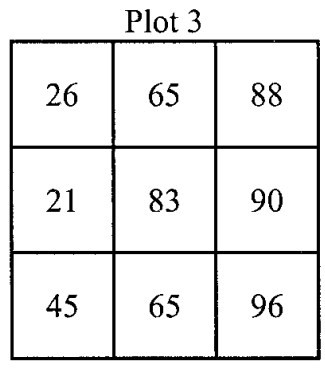

24

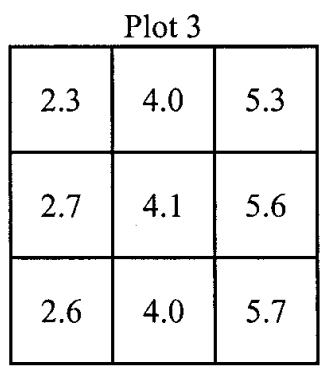

0.8

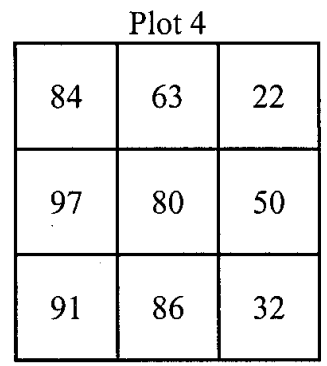

23

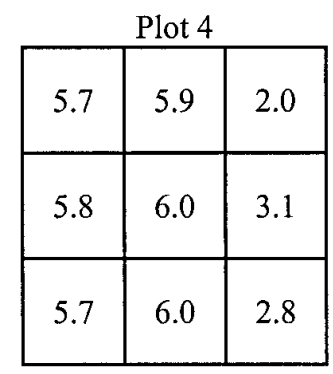

1.0

Fig. 1. Aphanomyces disease ratings of nine subplots ( 20 by $20 \mathrm{~m}$ ) within four main plots (60 by $60 \mathrm{~m}$, two/location). Grower-cooperators previously had not observed root rot in plots 1 and 3, but there was a history of Aphanomyces root rot in plots 2 and 4 . A, Index values of soil based on mean of 11 sites/subplot; eight soil cores were collected per site $(5.5 \mathrm{~cm}$ in diameter by $15 \mathrm{~cm}$ in depth in a 3-m length of row in late June to early July 1994$)$, combined and assayed ( 25 sugar beet seed per five pots) in the greenhouse; at 4 weeks after planting, seedlings were indexed for root rot ( 0 -to- 100 scale, where $0=$ healthy and $100=$ all plants dead). B, Root rot ratings in field in September 1994 based on mean of plants rated at 11 sites/subplot (all roots within a 3 -m length of row or site, the same as for soil collection) on a 0 -to-7 scale $(0=$ healthy, $7=$ root completely rotted $)$. Least significant difference values at $P=0.05$ within main plots. 
many values were $>2.5$. In plot 2 (historically diseased), root rot ratings usually were $>3.5$ except in the bottom center subplot, where most values were $<3$.

Variance-to-mean ratios of disease ratings in the field were $<1$ in three of the four main plots (Table 1), indicating a tendency toward a uniform distribution of disease severity among plots. The single main plot that had a variance-to-mean ratio $>1$ was the plot with the lowest disease severity.

Disease severity was distributed randomly among subplot samples (data not shown). Specifically, in all 36 subplots, the Poisson distribution could not be rejected as an appropriate model for describing disease data within subplots based upon the index of dispersion values $\left(\chi^{2}<18.3 ; P>\right.$ 0.05 ). Variance-to-mean ratios were $<1$ in 34 of the 36 subplots, indicating that disease was evenly distributed among sampling sites within the plots. The two subplots having variance-to-mean ratios $>1$ were located in the previously disease-free plot at the Moorhead, MN site and had low (index values $<2$ ) to moderate (index values $>2$ and $<3$ ) disease severity.

Among all samples, there was a positive correlation between root rot index values in the greenhouse and root rot ratings taken in the field ( $r=0.72 ; P<0.01)$. Correla- tion between greenhouse root rot index values and disease ratings in the field were highly significant in three out of four main plots $(r=0.59,0.68$, and $0.73 ; P<0.01)$. Plot 2 had a much smaller, but significant, correlation $(r=0.2, P<0.05)$ between greenhouse root rot index values and disease ratings in the field. In plot 2, ranges of values in the greenhouse bioassay (Fig. 1A) and field disease ratings (Fig. 1B) were narrower than those of the other three main plots.

\section{DISCUSSION}

Root rot index values indicated that inoculum of $A$. cochlioides was aggregated in soil at midseason, but Aphanomyces root rot on sugar beet was uniformly distributed in fields at harvest. Similar discrepancies in spatial pattern of inoculum of soilborne plant pathogens and disease have been reported for Sclerotinia minor on lettuce (6) and Rhizoctonia spp. on tall fescue turf (11). The uniform distribution of root rot at harvest can be attributed to several possible factors, including the potential redistribution of pathogen inoculum over the growing season, extensive root growth that overcomes inoculum aggregation, or inoculum densities that, although aggregated, are all above some minimum threshold required for infection. In our study, root rot index values for soil samples collected in mid- to late June ranged from 1 to 100 , indicating a wide range of inoculum densities. Disease was not observed in the field at this time, however, because soil moisture was not adequate for infection. Beginning at the time soil samples were collected and extending through harvest, 21 and $25 \mathrm{~cm}$ of precipitation fell at Wahpeton and Moorhead, respectively (18 and $31 \%$ above average, respectively; 2), which provided abundant soil moisture that is favorable for root infections. Lateral roots of sugar beet, which are distributed along the tap root to a depth of $20 \mathrm{~cm}$ and correspond to the zone where most inoculum occurs (12), are well established by mid- to late June (18). These fibrous roots extend laterally by $0.4 \mathrm{~cm}$ per day from 2 through 11 weeks after planting (corresponds to late May through early August in our study) and are intermingled among plants growing in the same and adjacent rows (18). As soil is infiltrated during this period of abundant lateral root growth, the probability of encountering inoculum of $A$. cochlioides is increased, especially when inoculum densities are high.

Infections originate from inoculum in soilborne debris, usually zoospores produced from germinating oospores (14). A prolonged wet period, as occurred in our

\section{A}
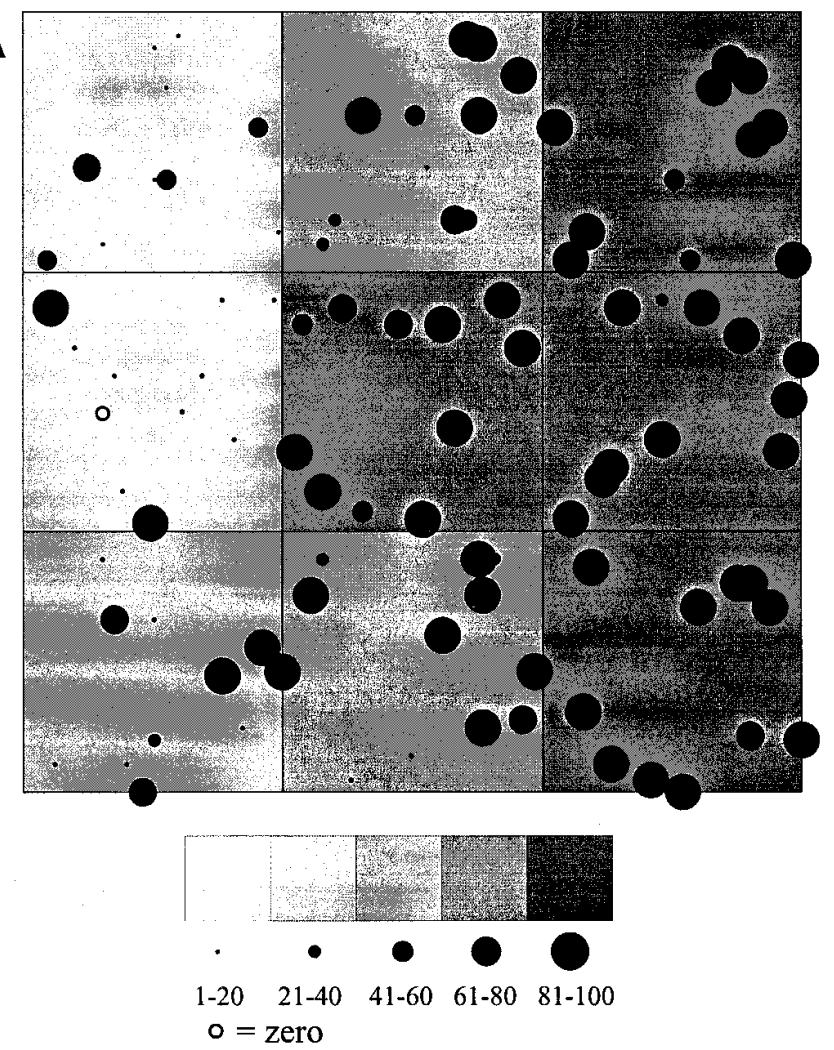

Greenhouse Index
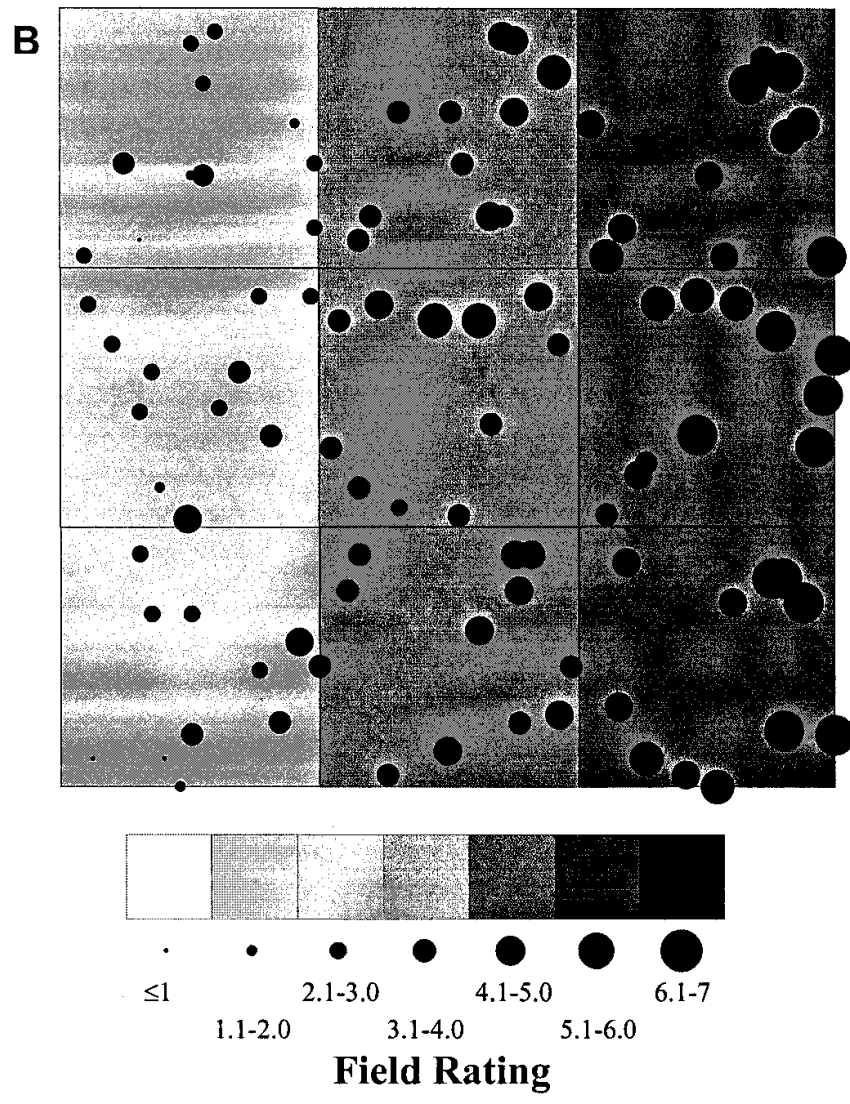

Fig. 2. Aphanomyces disease ratings in 99 sites (11/subplot) of one main plot (60 by $60 \mathrm{~m}$ ) in a Wahpeton, ND field that previously was described as disease-free. A, Soil index values based on eight soil cores collected per site $(5.5 \mathrm{~cm}$ in diameter by $15 \mathrm{~cm}$ in depth in a 3 -m length of row in late June to early July 1994) that were combined and assayed ( 25 sugar beet seed per five pots) in the greenhouse; at 4 weeks after planting, seedlings were indexed for root rot $(0$-to- 100 scale, where $0=$ healthy and $100=$ all plants dead $) . \mathbf{B}$, Root rot ratings in field in September 1994, based on mean of plants rated/site (all roots within a 3 -m length of row or site, the same as for soil collection) on a 0 -to 7 scale $(0=$ healthy, $7=$ root completely rotted). 
study, undoubtedly enhanced conditions favorable for infection, but it is impossible to relate this increased disease potential to a possible increase in inoculum density because we did not repeat soil assays when roots were rated in September. Whether $A$. cochlioides produces multiple cycles of zoospore inoculum in the field during a season and whether it spreads from healthy to diseased roots is unknown. Pfender and Hagedorn (15) found that A. euteiches spreads from infected to healthy pea plants. Dissemination of inoculum also is attributed to movement of diseased host plants and infested soil via wind, flowing water, tools, agricultural machinery, and humans (14).

Aggregation of inoculum of A. cochlioides in fields not planted to sugar beet for 3 years is likely to reflect past aggregation of disease in the field, spatial variation in pathogen survival, and patterns of soil and inoculum movement. Microscopic examination reveals that oospore populations decline as infected sugar beet debris buried in soil decomposes (C. E. Windels, unpublished data). After 3 years in the absence of a sugar beet crop (as in our fields), an aggregated pattern of inoculum is likely to reflect the distribution of remaining, oospore-infected debris.

Soil root rot indices at midseason correlated positively with disease ratings at harvest in three of the four main plots. Similar relationships have been reported for other soilborne pathogens $(5,8,15,16)$. Monitoring of soil index values and disease development throughout the season of our study may have helped relate soil index values to the onset of disease and the severity and distribution of Aphanomyces root rot at harvest.

Aphanomyces root rot occurred in the previously reported disease-free plots at both locations. At Wahpeton, disease ratings were nearly equally severe in the plot previously reported as disease-free compared with the plot with a history of disease. In the historically disease-free plot at Moorhead, there was a low to high gradient of soil root rot indices and root rot ratings from the west to east side of the plot. The east side of the plot also had a slight depression in topography which would tend to be wetter than the rest of the plot and thus more prone to Aphanomyces root rot. Discrepancies between previous reports of no disease and the presence of disease in these plots may have occurred because the producers miscalculated the location of disease-free areas. Other possibilities are that disease symptoms were mild and not noticed in previous seasons, inoculum of A. cochlioides had spread from diseased to surrounding areas, or inoculum increased on roots of weed hosts during the years between sugar beet crops (14).

The soil root rot index values derived from the greenhouse assay provided an indication of relative activity and density of inoculum that correlated with root rot severity at harvest. The aggregated distribution of inoculum of $A$. cochlioides at midseason, however, did not predict the uniform distribution of disease at harvest when soil was wet (and favorable for infections) for an extended period. The dynamics of how inoculum density relates to onset, spread, and rate of disease development throughout the sugar beet growing season needs clarification.

\section{ACKNOWLEDGMENTS}

We thank D. Jacobsen and J. Link for field research sites; D. Braaten and P. Beech, Agriculturists for American Crystal Sugar Co. and Minn-Dak Farmers Cooperative, respectively, for identifying fields; and J. Flor and J. Brantner for assistance with the figures.

\section{LITERATURE CITED}

1. Beale, J. W., Windels, C. E., and Kinkel, L. L. 1995. Relationship of Aphanomyces cochlioides populations to sugar beet root rot severity in fields. (Abstr.) Phytopathology 85:1134.

2. Beard, L., ed. 1996. North Dakota Agricultural Statistics. Vol. 65. North Dakota Agricultural Statistical Services, Fargo.

3. Byford, W. J. 1975. Observations on the occurrence of Aphanomyces cochlioides in agricultural soils in England. Trans. Br. Mycol. Soc. 65:159-162.

4. Cooke, D. A., and Scott, R. K., eds. 1993. The Sugar Beet Crop: Science into Practice. Chapman \& Hall, London.

5. Crowe, F. J., Hall, D. H., Greathead, A. S., and Baghott, K. G. 1980. Inoculum density of Sclerotium cepivorum and the incidence of white rot of onion and garlic. Phytopathology 70:64-69.

6. Dillard, H. R., and Grogan, R. G. 1984. Relationship between sclerotial populations of
Sclerotinia minor and the incidence of lettuce drop. (Abstr.) Phytopathology 74:839.

7. Duffus, J. E., and Ruppel, E. G. 1993. Diseases. Pages 369-372 in: The Sugar Beet Crop: Science into Practice. D. A. Cooke and R. K. Scott, eds. Chapman \& Hall, London.

8. Ferrin, D. M., and Mitchell, D. J. 1986. Influence of initial density and distribution of inoculum on the epidemiology of tobacco black shank. Phytopathology 76:1153-1158.

9. Fink, H. C., and Buchholtz, W. F. 1954 Correlation between sugar beet crop losses and greenhouse determinations of soil infestation of Aphanomyces cochlioides. Proc. Am. Soc. Sugar Beet Technol. 8:252-259.

10. Leach, L. D. 1986. Pages 4-8 in: Compendium of Beet Diseases and Insects. E. D. Whitney and J. E. Duffus, eds. American Phytopathological Society Press, St. Paul, MN.

11. Martin, S. B., Campbell, C. L., and Lucas, L. T. 1983. Horizontal distribution and characterization of Rhizoctonia spp. in tall fescue turf. Phytopathology 73:1064-1068.

12. McKeen, W. E. 1949. A study of sugar beet rootrot in southern Ontario. Can. J. Res. Sect. C, Bot. Sci. 27:284-311.

13. Ott, L. 1977. An Introduction to Statistical Methods and Data Analysis. Duxbury Press, North Scituate, MA.

14. Papavizas, G. C., and Ayers, W. A. 1974 Aphanomyces species and their root diseases in pea and sugar beet. U.S. Dep. Agric. Agric. Res. Serv. Tech. Bull. 1485. Washington, DC.

15. Pfender, W. F., and Hagedorn, D. J., 1983. Disease progress and yield loss in Aphanomyces root rot of peas. Phytopathology 73:11091113.

16. Pullman, G. S., and DeVay, J. E. 1982. Epidemiology of Verticillium wilt of cotton: A relationship between inoculum density and disease progression. Phytopathology 72:549554.

17. Schneider, C. L. 1964. Classification of sugar beet strains for resistance to Aphanomyces cochlioides in greenhouse tests. Am. Soc. Sugar Beet Technol. J. 12:651-656.

18. Scott, R. K., and Jaggard, K. W. 1993. Crop physiology and agronomy. Pages 179-237 in: The Sugar Beet Crop: Science into Practice. D. A. Cooke and R. K. Scott, eds., Chapman \& Hall, London.

19. Southwood, T. R. E., and Henderson, P. A. 2000. Ecological Methods. 3rd ed. Blackwell Science, Oxford.

20. Windels, C. E., and Lamey, H. A. 1998. Identification and control of seedling diseases, root rot, and rhizomania on sugar beet. N. D. State Univ. Ext. Serv./Univ. Minn. Ext. Serv. PP-1142 BU-7192-S.

21. Windels, C. E., and Nabben-Schindler, D. J. 1996. Limitations of a greenhouse assay for determining potential of Aphanomyces root rot in sugar beet fields. J. Sugar Beet Res. 33:1-13. 